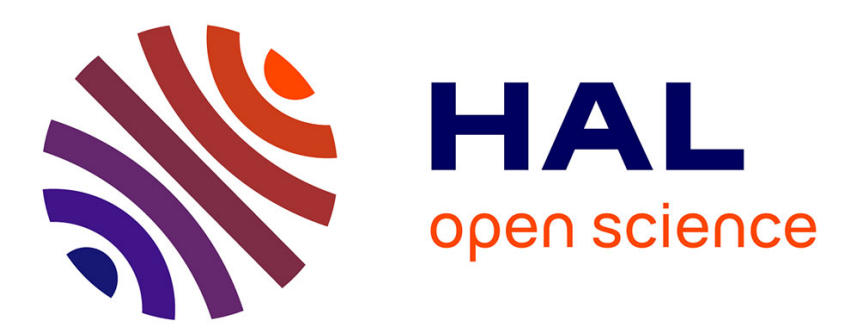

\title{
Comparison of three pollination methods for Eucalyptus argophloia, a small-flowered eucalypt
}

\author{
Bruce W. Randall, David A. Walton, David J. Lee, Helen M. Wallace
}

\section{To cite this version:}

Bruce W. Randall, David A. Walton, David J. Lee, Helen M. Wallace. Comparison of three pollination methods for Eucalyptus argophloia, a small-flowered eucalypt. Annals of Forest Science, 2015, 72 (1), pp.127-133. 10.1007/s13595-014-0407-z . hal-01284161

\section{HAL Id: hal-01284161 \\ https://hal.science/hal-01284161}

Submitted on 7 Mar 2016

HAL is a multi-disciplinary open access archive for the deposit and dissemination of scientific research documents, whether they are published or not. The documents may come from teaching and research institutions in France or abroad, or from public or private research centers.
L'archive ouverte pluridisciplinaire HAL, est destinée au dépôt et à la diffusion de documents scientifiques de niveau recherche, publiés ou non, émanant des établissements d'enseignement et de recherche français ou étrangers, des laboratoires publics ou privés. 


\title{
Comparison of three pollination methods for Eucalyptus argophloia, a small-flowered eucalypt
}

\author{
Bruce W. Randall • David A. Walton • David J. Lee • \\ Helen M. Wallace
}

Received: 4 December 2013 / Accepted: 8 July 2014 / Published online: 30 July 2014

(C) INRA and Springer-Verlag France 2014

\begin{abstract}
- Context Most studies assess pollination success at capsule maturity, and studies of pre-zygotic processes are often lacking.

- Aims This study investigates the suitability of controlled pollination for a potential forestry plantation species, Eucalyptus argophloia, by examining pre- and post-zygotic pollination success.

- Methods Pollen tube development, capsule set and seed set are compared following three-stop pollination, artificially induced protogyny (AIP), AIP unpollinated and open pollination. The fecundity of stored pollen was compared with that of fresh pollen.

- Results Three-stop pollination, AIP and open pollination had similar numbers of pollen tubes, but AIP unpollinated had none. Open pollination produced significantly more capsules and total number of seeds than the other treatments. There were significantly more seeds per retained capsule for
\end{abstract}

\section{Handling Editor: Ricardo Alia \\ Contribution of the co-authors Bruce W. Randall: collaboratively de- signing the experiments, undertaking the experiments, collecting and analysing data and drafting and editing the manuscript. \\ David A. Walton: collaboratively designing the experiments and discussing, editing and submitting the manuscript. \\ David J. Lee: providing equipment and access to the experimental site, doing field work and reviewing the manuscript. \\ Helen M. Wallace: coordinating the project, collaboratively designing the experiments, supervising the experiments, discussing data and results and editing the manuscript.}

B. W. Randall $\cdot$ D. A. Walton $(\bowtie) \cdot$ D. J. Lee $\cdot$ H. M. Wallace Faculty of Science, Health, Education, and Engineering, University of the Sunshine Coast, Maroochydore, QLD 4558, Australia e-mail: dwalton3@usc.edu.au

D. J. Lee

Department of Agriculture Fisheries and Forestry, P.O. Box 395, Gympie, QLD 4570, Australia the open pollination and three-stop pollination treatments than for the AIP and AIP unpollinated pollination treatments. There were no significant differences relative to the age of pollen.

- Conclusions Pre-zygotic success in terms of pollen tubes was similar for open-pollinated, three stop and AIP, but was not reflected in post-zygotic success when the open pollination and three-stop method produced significantly more seeds per retained capsule than the AIP treatments and open pollination yielded more seeds. Capsule set and total seed set for open pollination, and fewer capsules in controlled pollinations, may reflect physical damage to buds because of the small E. argophloia flowers. Suitable alternative breeding strategies other than controlled pollinations are discussed for this species.

Keywords Eucalyptus argophloia · Pollination methods · Pollen tubes $\cdot$ Seed set $\cdot$ Pollen age

\section{Introduction}

Australia's forests are dominated by an iconic single group of plants, the "gum trees" (Eucalyptus, Corymbia and Angophora spp.). The genus Eucalyptus has been exploited worldwide for raw material for pulp, paper and solid-wood products and is the most widely planted hardwood species in the world (Turnbull 1999). In 2008, worldwide plantings were estimated at 19.61 million ha (Nichols et al. 2010). Demand for hardwood timber for sawlogs is increasing in Australia, and suitable species that are adapted to marginal, low-rainfall areas are needed (Lee et al. 2010).

Breeding for genetic improvement of eucalypts is still at an early stage (Horsley et al. 2007). Eucalypt species preferentially outcross; however, self-pollination is common (Griffin et al. 1988). Three techniques are commonly used to produce 
seed of known parentage in eucalypts: three-stop pollination (Ellis et al. 1991; Sedgley and Smith 1989), one-stop pollination (Harbard et al. 1999; Williams et al. 1999) and artificially induced protogyny (AIP) techniques (Assis et al. 2005; Horsley et al. 2010). The three-stop pollination method requires flowers to be emasculated and bagged to prevent unwanted self- or cross-pollen from accessing the stigma. This system is expensive and labour-intensive with risks of increased mortality due to damage to buds during emasculation (Dickinson et al. 2010; Van Wyk 1977). Most eucalypts are protandrous, and the stigma is not receptive for up to 10 days after anthesis (Harbard et al. 1999; Randall et al. 2012). The one-stop pollination method reduces the risk of pollinating when the stigma is not receptive by removing the tip of the style and may also overcome incompatibility reactions that block pollen tube growth (Patterson et al. 2004; Trindade et al. 2001). This method also reduces the number of operator visits and therefore is less expensive than the three-stop method (Williams et al. 1999). The tip of the style is also removed in the AIP method and it has similar advantages to one-stop pollination (Dickinson et al. 2010; Tibbits 1989); however, there may be an increased risk of self-pollination because the flowers are not emasculated (Assis et al. 2005; Randall et al. 2012). This method allows pollination before stigma receptivity and increases the quantity of seed produced in Eucalyptus globulus, E. grandis, E. smithii and E. macarthurii (Horsley et al. 2010; Patterson et al. 2004; Williams et al. 1999). Although Tibbits (1989) found AIP to be successful in another small-flowered species, E. nitens, Williams et al. (1999) found this treatment to be unsuccessful in the same species.

There are many stages involved in successful reproduction for eucalypts. Pollen must adhere to the stigma, successfully grow down the style and fertilize the ovule and then seeds must develop and the capsule be retained until maturity (Dickinson et al. 2013). Most studies assess pollination success at capsule maturity, and studies of pre-zygotic processes, i.e. before ovules are fertilized, are often lacking (Lord 2000). Pre-zygotic pollination success is not always mirrored in success of seed production, and high seed production does not always indicate efficient pollination (Dickinson et al. 2012). A few studies have examined aspects of both prezygotic and post-zygotic success of self- and crosspollination treatments. There was no difference between self- and cross-pollination in pollen tube growth and fertilized ovules for Eucalyptus regnans (Sedgley et al. 1989). For E. globulus, there were more healthy, fertilized ovules from cross- compared to self-pollination, and the mechanism of self-incompatibility appeared to have both late pre- and postzygotic components (Pound et al. 2002a). Another study to investigate the site of action of incompatibility found no difference in number of pollen tubes in the style (pre- zygotic) but, in contrast, almost complete lack of self-seed production (post-zygotic) compared with cross-pollinated seed (Pound et al. 2002b). Reciprocal and advanced generation hybrids of Corymbia citriodora and Corymbia torelliana showed high fertility between all crosses as demonstrated by pollen tubes, and early differences in pre-zygotic reproductive success were carried through to seed maturity for $C$. torelliana females, but not for females of $C$. citriodora ssp. citriodora (Dickinson et al. 2013). There is little knowledge of prezygotic and post-zygotic success for different pollination methods.

Stored pollen is often required for controlled crosses when fresh pollen is unavailable due to asynchronous flowering of species (Horsley et al. 2007). The fecundity of stored pollen is an important factor for successful controlled pollination; for example, pollen quality and in vitro germination have been found to decrease with age and increasing storage temperature for E. smithii, E. nitens and E. grandis (Horsley et al. 2007).

Eucalyptus argophloia Blakely (Western White Gum or Chinchilla White Gum) is limited to a small population in a low-rainfall area $(650-700 \mathrm{~mm}$ per year) of Southeast Queensland, Australia (Brooker and Kleinig 2004). The species is listed as "vulnerable" by the Environment Protection and Biodiversity Conservation Act 1999 (Australia) and Nature Conservation Act 1992 (Queensland). E. argophloia is a fast-growing tree that produces strong, durable timber and is a potential plantation species in marginal, drier subtropical areas (Ngugi et al. 2004).

Previous work on E. argophloia has detected less pollen tube growth from one-stop pollination methods compared to other methods (Randall et al. 2012). The aims of this study are to examine pre-zygotic and post-zygotic reproductive success of different pollination treatments by comparing pollen tube growth, capsule set and seed set between three-stop pollination, AIP, AIP unpollinated and open pollination of E. argophloia. The study also compared pollen tube growth, capsule set and seed set between stored pollen and fresh pollen.

\section{Materials and methods}

\subsection{Study site and parental plants}

Pollination studies of E. argophloia were conducted in a seed orchard at the Dunmore State Forest on the Darling Downs, south-eastern Queensland $\left(27.34^{\circ} \mathrm{S} ; 151.04^{\circ} \mathrm{E}\right)$, between March 2009 and July 2009. Four 12-year-old E. argophloia trees with known parentage were selected as the maternal parent trees, and trees were blocks in a randomized complete block design. 


\subsection{Pollination methods}

Four pollination method treatments were used for E. argophloia: (1) three-stop pollination using a withinspecies freshly extracted pollen polymix (Sedgley and Smith 1989; Van Wyk 1977), (2) AIP using the same pollen polymix (Assis et al. 2005; Horsley et al. 2010), (3) AIP without any applied pollen (AIP unpollinated) and (4) open pollination where flowers were not manipulated. Thirty flower buds per treatment were treated ( $n=30$ replicates per tree per treatment) for each of four trees for pollen tube analysis, and three replicates of 20 flower buds per treatment $(n=60$ flower buds per tree per treatment) were treated for each of four trees for capsule retention and seed set. Bunches of 20 flower buds were considered as one replicate for statistical analysis of capsule retention and seed set. Treatments were fully randomized on trees with trees regarded as blocks in a randomized block design.

Flower buds in the three-stop pollination treatment were emasculated just prior to anthesis, when the operculum changed from green to brown, approximately 2 days prior to operculum lift. The opercula were removed and individual flower buds emasculated using a curved scalpel blade. All surplus flower buds in each bunch were removed at emasculation. After emasculation, each replicate was bagged with a polyester exclusion bag to exclude pollinators. Bags were removed 6 days after emasculation (Randall et al. 2012), and a freshly extracted pollen polymix from three unrelated E. argophloia trees was applied to each flower bud. A moistened match head was used to apply pollen, thus regulating the amount of pollen applied to each bud. Each match was discarded after use. Inflorescences were then re-bagged, and bags were not removed until 14 days after emasculation when flower buds for pollen tube analysis were collected.

Flower buds for the AIP and AIP unpollinated treatments were treated by removing the tip of the operculum and part of the style just prior to anthesis. Pollen was immediately applied to the cut style for the AIP treatment using a match as above. Replicates in the open pollination treatment were selected at the same stage as the other treatments and any excess flower buds removed. Open treatments were not manipulated or bagged.

\subsection{Pollen storage treatments}

The three-stop pollination method was used for this study. Flower buds received one of four pollination treatments on four trees in a random block design. Pollens were obtained randomly when they were available, not from the same trees for each storage time, but from trees unrelated to the maternal trees. Pollens were (1) stored 1-year-old pollen, (2) pollen mix extracted from the extant flowering and stored for 1 month, (3) pollen extracted on the day of pollination and (4) fresh pollen applied directly from the anthers of another tree. Pollen sources were unrelated to the female trees. Treatments were fully randomized on four trees with trees as blocks.

Thirty flower buds per treatment were treated $(n=30$ flower buds per tree per treatment) for each of four trees for pollen tube analysis, and three replicates of 20 flower buds per treatment ( $n=60$ flower buds per tree per treatment) were treated for each of four trees for capsule retention and seed set. Bunches of 20 flower buds were considered as one replicate for statistical analysis of capsule retention and seed set.

The year-old pollen was a polymix from three unrelated trees that had been collected during the previous flowering season. One-month-old similarly stored pollen from the extant flowering was collected from two unrelated trees and prepared in a similar manner to the year-old pollen. Anthers were removed with forceps and desiccated over silica gel for 24 $48 \mathrm{~h}$ to promote dehiscence. After sieving, the pollen mix was stored in gelatine capsules at $5{ }^{\circ} \mathrm{C}$ in jars with desiccant. When fresh, extracted pollen was used, a pollen mix was collected from two unrelated trees just prior to anthesis and prepared as above; however, it was only desiccated for $1-2 \mathrm{~h}$ so that the pollen was as fresh as possible. When fresh pollen direct from the anthers was used, flowers were harvested from another tree for direct pollination.

\subsection{Fluorescence microscopy and capsule harvest}

Flowers for pollen tube examination were collected 7 days after pollination and stored in acetic ethanol (1 part glacial acetic acid: 3 parts ethanol) for later processing. Samples were processed as previously described (Martin 1959, Randall et al. 2012). The capsules for seed production were harvested 224 days after emasculation, just prior to the valves' opening. The numbers of pollen grains on the stigma and numbers of pollen tubes in the upper, middle and lower style were recorded. The numbers of retained capsules per treatment, the total number of seeds per flower pollinated and the total seed counts per retained capsule were recorded.

\subsection{Statistical analysis}

The percentage of capsules retained per pollination treatment was calculated. All data were analysed using SPSS version 19 (SPSS Science, Chicago). Data for pollen grains on the stigma, pollen tubes in the style, total capsules retained, capsule retention (\%) and seeds per capsule pollinated for the pollination experiment did not satisfy the assumptions of parametric testing; therefore, Kruskal-Wallis and Mann-Whitney $U$ tests were used to test for significant difference $(P<0.05)$ and a Bonferroni correction factor was applied to determine the appropriate level of significance (Sokal and Rohlf 1995). Data for seeds per capsule retained for the pollination methods were analysed by a mixed model with treatment and tree as 
fixed effects using tests for least significant difference for comparison of means $(P<0.05)$. Data for capsule retention $(\%)$, seeds per capsule pollinated and seeds per capsule retained for the pollen storage experiment also did not satisfy the assumptions of parametric tests and were analysed as above.

\section{Results}

The three-stop pollination treatment, AIP and open pollination produced more pollen tubes in the upper style, the mid style and the lower style (Kruskal-Wallis and Mann-Whitney tests with a Bonferroni correction factor, $P=0.018,0.023,0.012$, respectively) than the AIP unpollinated treatment, which produced no pollen tubes (Table 1). There were no differences in pollen tubes in the upper, mid and lower style for the threestop pollination, AIP and open pollination treatments (Table 1). There was no significant difference in pollen grain adhesion to stigmas for the four pollination treatments (Table 1).

The open-pollinated treatment retained a significantly higher percentage of capsules than all other treatments (Kruskal-Wallis and Mann-Whitney tests with a Bonferroni correction factor, $P<0.001$ ) (Fig. 1a). There was no difference between the other three treatments. The open-pollinated treatment also produced a significantly greater total number of seeds per capsule pollinated than all the other treatments (Kruskal-Wallis and Mann-Whitney tests with a Bonferroni correction factor, $P<0.001$ ) (Fig. 1b). The open-pollinated and three-stop pollination treatments were not significantly different for seeds per retained capsule but produced significantly more seeds than the AIP and AIP unpollinated pollination treatments (mixed model ANOVA, $P=0.005$ ) (Table 2).

Table 1 Pollen adhesion and pollen tube growth for the pollination treatments on Eucalyptus argophloia in south-eastern Queensland

\begin{tabular}{|c|c|c|c|c|}
\hline \multirow[t]{2}{*}{ Treatment } & \multirow{2}{*}{$\begin{array}{l}\text { Pollen grains } \\
\text { On stigma }\end{array}$} & \multicolumn{3}{|c|}{ Pollen tubes } \\
\hline & & $\begin{array}{l}\text { Upper } \\
\text { style }\end{array}$ & $\begin{array}{l}\text { Middle } \\
\text { style }\end{array}$ & $\begin{array}{l}\text { Lowe } \\
\text { style }\end{array}$ \\
\hline AIP & $32.0 \mathrm{a}$ & $7.9 \mathrm{a}$ & $3.9 \mathrm{a}$ & $0.5 \mathrm{ab}$ \\
\hline AIP unpollinated & $5.2 \mathrm{a}$ & $0.0 \mathrm{~b}$ & $0.0 \mathrm{~b}$ & $0.0 \mathrm{~b}$ \\
\hline Three stop & $19.9 \mathrm{a}$ & $5.7 \mathrm{a}$ & $3.3 \mathrm{a}$ & $2.8 \mathrm{a}$ \\
\hline Open pollinated & $23.6 \mathrm{a}$ & $0.7 \mathrm{ab}$ & $0.4 \mathrm{ab}$ & $0.5 \mathrm{ab}$ \\
\hline$P$ value & NS & 0.02 & 0.02 & 0.01 \\
\hline
\end{tabular}

Values are mean numbers observed at each stigma or style location (SE). Values in the same column with different letters are significantly different (non-parametric Kruskal-Wallis and Mann-Whitney tests with a Bonferroni correction factor $)(P<0.05)$

NS not significant

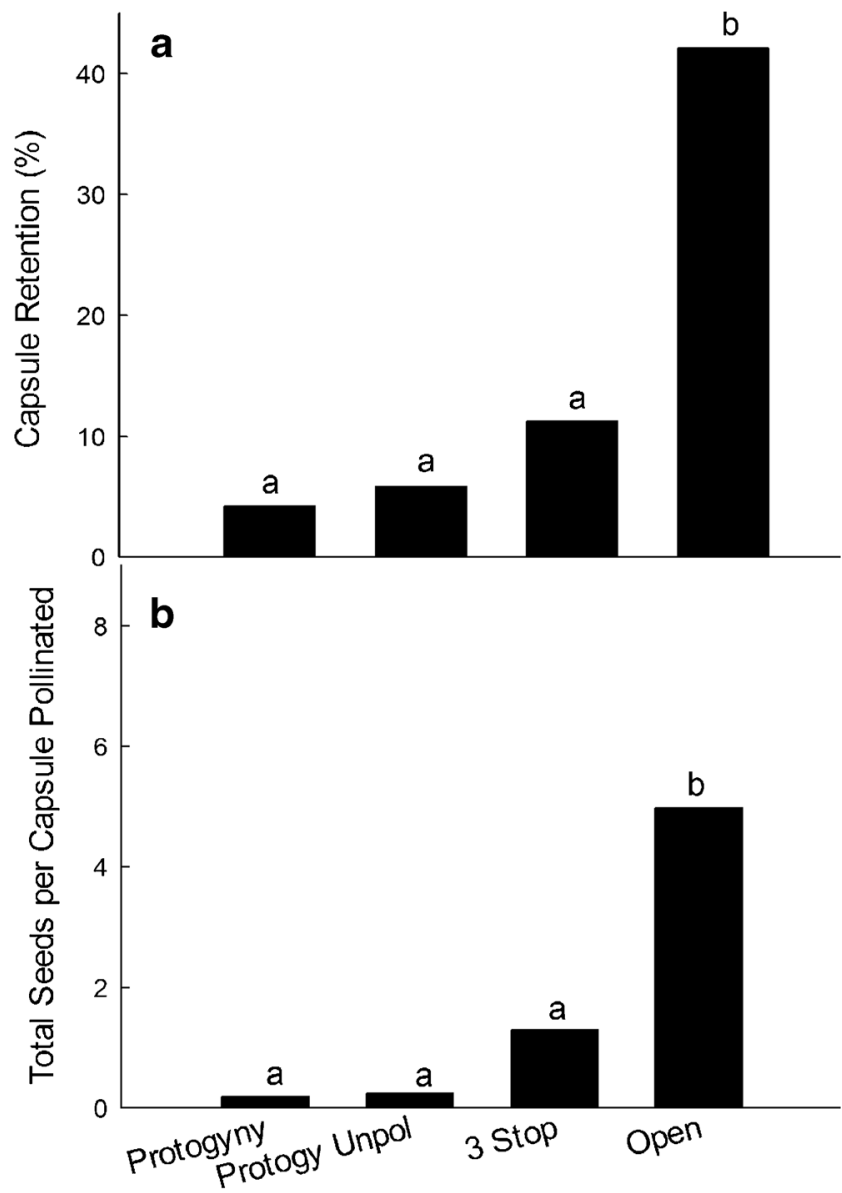

Fig. 1 Means for Eucalyptus argophloia pollination treatments: a capsule retention ( $\%$ of flowers pollinated), $\mathbf{b}$ total seeds per capsule pollinated. Treatments are AIP, AIP unpollinated (Protogy Unpol), three-stop pollination (3 Stop) and open pollinated (Open). Means in columns with different letters are significantly different $(P<0.05)$ (Kruskal-Wallis and Mann-Whitney tests with a Bonferroni correction factor)

Despite no pollen tubes being observed, capsules were retained and seed set for the AIP unpollinated treatment. There was a significant tree effect for seeds per capsule retained $(P=0.011)$. There was no significant difference for percentage of capsules retained, seed set per capsule

Table 2 The total number of capsules retained per pollination treatment (total and \%), number of trees with retained capsules and seeds per capsule retained (SE) for four pollination treatments of Eucalyptus argophloia. Data for seeds per capsule retained were analysed by a mixed model ANOVA with pollination treatment and maternal tree as factors $(P<0.05)$. Significance levels: $P=0.005$ (pollination treatment), $P=0.011$ (tree)

\begin{tabular}{lcll}
\hline Treatments & $\begin{array}{l}\text { Capsules } \\
\text { retained } \\
\text { per treatment }\end{array}$ & $\begin{array}{l}\text { Number of } \\
\text { trees with } \\
\text { capsules }\end{array}$ & $\begin{array}{l}\text { Seeds per capsule } \\
\text { retained (SE) }\end{array}$ \\
\hline AIP & $10(4.2 \%)$ & 4 & $5.1(1.9) \mathrm{b}$ \\
AIP unpollinated & $14(5.8 \%)$ & 4 & $4.9(2.5) \mathrm{b}$ \\
Three-stop pollination & $27(11.3 \%)$ & 4 & $11.8(2.8) \mathrm{a}$ \\
Open pollination & $101(42.1 \%)$ & 4 & $10.6(1.3) \mathrm{a}$ \\
\hline
\end{tabular}

Significance levels are $P<0.05$ 
pollinated and seeds per capsule retained using the year-old pollen, month-old pollen, freshly extracted pollen and pollen applied directly from another anther (Table 3).

\section{Discussion}

Our results showed that reproductive success was not a function of observed pre-zygotic reproductive success as shown by pollen tubes; for example, pollination method treatments that had similar numbers of pollen tubes in the lower style did not produce similar total seed set. However, these results do not preclude late pre-zygotic barriers affecting capsule and seed set such as in the ovules. The highest total seed set was in the open-pollinated treatment, in spite of no significant difference in pollen tube growth compared to the three-stop and AIP treatment. Higher seed production for the open-pollinated treatment was because more capsules were retained and was not due to more successful pollination. The AIP unpollinated treatment retained capsules and produced seed despite no pollen tubes being observed. This may have been because the sample size for pollen tube examination may not have been large enough to ensure capture of pollen tubes in this in vivo study. Capsule retention from pollinated buds is an important issue in forestry breeding programmes and is impacted by many parameters such as tree health (Collins and Callister 2010) and environmental factors such as rainfall (Brawner et al. 2013). Physiological and environmental processes that affect capsule retention need to be considered when interpreting pollination success in eucalypts and other plants.

Our study also shows that the open-pollinated buds had similar pollen tube growth to the manipulated treatments except AIP unpollinated, but retained many more capsules. The controlled pollination methods (AIP unpollinated, AIP and three-stop pollination) retained $12 \%$ or less of their capsules, whereas open pollination retained $\sim 40 \%$, similar to $6 \%$ capsule retention in E. grandis (Horsley and Johnson 2007), 5.6-15.5 \% for Corymbia hybrids (Dickinson et al. 2010) and 5-19\% for some E. grandis hybrids (Horsley et al.

Table 3 The percentage of capsules retained, seeds per pollinated flower and seeds per retained capsule (SE) of Eucalyptus argophloia for yearold, month-old, freshly extracted and fresh pollen treatments. The threestop pollination system was used to test the effect of pollen storage on pollination success. No significant differences between treatments were found (Kruskal-Wallis test, $P<0.05$ )

\begin{tabular}{llll}
\hline Treatments & $\begin{array}{l}\text { \% capsules } \\
\text { retained }\end{array}$ & $\begin{array}{l}\text { Seeds per } \\
\text { pollinated flower }\end{array}$ & $\begin{array}{l}\text { Seeds per } \\
\text { retained capsule }\end{array}$ \\
\hline Year old & 29.2 & 4.1 & 10.5 \\
Month old & 22.5 & 3.1 & 14.2 \\
Fresh extracted & 19.6 & 2.8 & 9.4 \\
Fresh & 17.9 & 2.3 & 9.6 \\
\hline
\end{tabular}

2010), but lower than $21 \%$ capsule retention for E. grandis hybrids (Assis et al. 2005), $64 \%$ for Eucalyptus urophylla (Horsley and Johnson 2007), $71 \%$ for E. grandis (Horsley et al. 2010) and $73 \%$ for E. globulus (Suitor et al. 2008) using the three-stop method.

The open pollinated treatment produced a greater overall seed set than the controlled 221 pollination treatments because it retained significantly higher numbers of capsules. This clearly shows that three-stop pollination can be as successful as open pollination in producing seeds per capsule; however, total seed production for this species will be higher for open pollination because of the high rate of capsule abortion with controlled pollinations.

Damage occurs to buds of E. argophloia because of the difficulty of using three-stop pollination and AIP on small buds, resulting in abortion which reduces capsule retention and total seed yield. Horsley et al. (2010) also found that when pollinating E. grandis, E. smithii and E. macarthurii, the AIP method resulted in the highest capsule abortion. In contrast, Assis et al. (2005) found that for E. grandis, open pollination had the lowest mean seeds per branch treated although this may have reflected reduced pollen availability in controlled environment (glasshouse) conditions compared with a natural setting. Minimizing bud damage in controlled pollinations is extremely important, as bud damage results in decreased capsule set and seed production. The buds of E. argophloia are only $0.4 \times 0.4 \mathrm{~cm}$ (Brooker and Kleinig 2004), smaller than those of many eucalypts and are much smaller than those evaluated in previous pollination studies (e.g. E. grandis $0.8 \times 0.7 \mathrm{~cm}$, E. nitens $0.7 \times 0.6 \mathrm{~cm}$, E. macarthurii $0.5 \times$ $0.6 \mathrm{~cm}$; Brooker and Kleinig 1999).

Horsley et al. (2010) suggested that damage to the buds of E. grandis, E. smithii $(0.7 \times 0.7 \mathrm{~cm})$ and $E$. macarthurii during emasculation due to small size of the buds was the cause of reduced seed set. Dickinson et al. (2010) also found lower capsule retention following AIP treatments in Corymbia hybrids which have large buds compared with E. argophloia and suggested that lower capsule retention may be due to increased physical damage resulting from the pollination method. The number of seeds per retained capsule from the threestop treatment was similar to open pollination, indicating that this procedure was capable of producing seed if capsules were retained. The two AIP methods tested (pollinated and unpollinated) had similar low levels of capsules retained ( $\sim 5 \%)$ and seeds per capsule retained (10 to 14). Seeds in the AIP unpollinated treatment suggest that the polyester pollination bags were not effective at excluding small pollinators, and self or foreign pollen was introduced. Horsley et al. (2010) and Dickinson et al. (2010) both report that unpollinated treatments produced seeds confirming a pollen source.

The current study shows that controlled pollination methods are not suitable for a small-flowered species such 
as E. argophloia, and other strategies are needed for genetic improvement. Forestry breeding programmes could consider mass supplementary pollination (MSP) and nursery selection using screening-based morphological markers as an alternative method of producing improved seed set from crosspollination in small-flowered species (Abasolo et al. 2012; Barbour et al. 2002, 2003, 2007). Mass supplementary pollination is a method where the desired pollen parent is added to open-pollinated flowers and does not require style cutting, emasculation or bagging (Wallace et al. 1996; Patterson et al. 2004; Suitor et al. 2008; Collins and Callister 2010). Patterson et al. (2004) found MSP to be suitable for large-scale production of $E$. globulus seeds. This method is also costly but may be justified when specific hybrids are the desired outcome. Many Eucalyptus and Corymbia species hybridize readily, and there is potential for development of hybrids to establish hardwood plantations (Dickinson et al. 2010, 2012, 2013). MSP would be useful for developing suitable hybrids if combined with pedigree recovery programmes using microsatellite molecular markers (Gea et al. 2007). Pedigree recovery is also costly and still needs refinement but may be justified by the generation of valuable hybrids (Gea et al. 2007). Another option is a simple open-pollinated genetic improvement strategy. There is some risk of inbreeding depression in open pollination (White et al. 2007), but practical, theoretical, logistical and low cost advantages are claimed for it (Griffin 1982; Cotterill 1986; Franklin 1986; Rockwood et al. 1989). However, open pollination will not produce targeted hybrids.

There were no significant differences between year-old pollen, month-old pollen, freshly extracted pollen and pollen applied directly from another anther for capsules retained, seed set and seeds per capsule. These findings contrast with those of Horsley et al. (2007) who found that in many eucalypts the best method of pollen storage was cryo-preservation, and fresh pollen was more viable than refrigerated pollen, but are supported by Randall et al. (2012) who found no significant difference between production of pollen tubes from using stored pollen, fresh extracted pollen polymix and applying fresh pollen directly from anthers of E. argophloia. However, the current results could be viewed with caution without conducting pollen fertility tests under controlled conditions in vitro, due to the large number of variables involved in in vivo experiments such as this study. In addition, because pollens of different ages were not obtained from the same trees, the storage effect may have confounded tree effects.

Results from this study suggest that the three-stop and AIP pollination methods damage the E. argophloia capsule and reduce capsule retention and seed yield. Controlled pollination is a problematic breeding strategy for this species. Alternative strategies for genetic improvement of this species may be simple open-pollinated genetic improvement or mass supplementary pollination followed by nursery selection based on morphological traits. Where specific hybrids of this species are produced, mass supplementary pollination followed by nursery selection based on morphological traits or pedigree recovery using microsatellite markers may be options.

Acknowledgments The authors wish to thank the Australian Research Council for financial assistance, John Oostenbrink (Agri-Science Queensland, Gympie) for technical support and Agri-Science Queensland, Department of Agriculture, Fisheries and Forestry, for providing access to trial sites and equipment used in this study.

Funding This work was supported by the Australian Research Council linkage grant number LP0562678.

\section{References}

Abasolo M, Lee DJ, Shepherd M (2012) Identification of intersectional Corymbia hybrids based on seedling morphology improves with parental divergence. Forest Ecol Manag 279:189-202

Assis T, Warburton P, Harwood C (2005) Artificially induced AIP: an advance in the controlled pollination of Eucalyptus. Aust Forest 68: $27-33$

Barbour RC, Potts BM, Vaillancourt RE, Tibbits WN, Wiltshire JE (2002) Gene flow between introduced and native Eucalyptus species. New For 23:177-191

Barbour RC, Potts BM, Vaillancourt RE (2003) Gene flow between introduced and native Eucalyptus species: exotic hybrids are establishing in the wild. Aust J Bot 51:429-439

Barbour RC, Potts BM, Vaillancourt RE (2007) Gene flow between introduced and native Eucalyptus species: morphological analysis of tri-species and backcross hybrids involving E. nitens. Silv Genet $56: 127-133$

Brawner JT, Lee DJ, Meder AR, Almeida A, Dieters MJ (2013) Classifying genotype by environment interactions for targeted germplasm deployment with a focus on Eucalyptus. Euphytica 191:403414

Brooker M, Kleinig D (1999) Field guide to eucalypts - volume 1 southeastern Australia, 2nd edn. Bloomings Books, Melbourne, pp 70186

Brooker M, Kleinig D (2004) Field guide to eucalypts-volume 3 Northern Australia, 2nd edn. Bloomings Books, Melbourne, p 240

Collins SL, Callister AN (2010) Genetic and environmental influences on capsule retention following controlled pollination of Eucalyptus globulus flowers. Aust Forest 73:198-203

Cotterill PP (1986) Genetic gains expected from alternative breeding strategies including simple low cost options. Silv Genet 35:212-223

Dickinson GR, Wallace HM, Lee DJ (2010) Controlled pollination methods for creating Corymbia hybrids. Silv Genet 59:233-241

Dickinson GR, Lee DJ, Wallace HW (2012) The influence of pre- and post-zygotic barriers on interspecific Corymbia hybridization. Ann Bot 109:1215-1226

Dickinson GR, Lee DJ, Wallace HW (2013) Reciprocal and advanced generation hybrids between Corymbia citriodora and C. torelliana: forestry breeding and the risk of gene flow. Ann Forest Sci 70:1-10

Ellis MF, Sedgley M, Gardner JA (1991) Interspecific pollen-pistil interaction in Eucalyptus L'Hér. (Myrtaceae): the effect of taxonomic distance. Ann Bot 68:185-194

Franklin EC (1986) Estimation of genetic parameters through four generations of selection in Eucalyptus grandis demonstrate valuable methodology. In: Proceedings of the International Union of Forest Research Organizations (IUFRO), Conference on Breeding Theory, Progeny Testing and Seed Orchards, Williamsburg, VA, pp 192-196 
Gea LD, McConnochie R, Wynyard S (2007) Parental reconstruction for breeding, deployment and seed-orchard management of Eucalyptus nitens. New Zealand J Forest Sci 37:23-26

Griffin AR (1982) Clonal variation in radiata pine seed orchards. I. Some flowering, cone and seed production traits. Aust J Forest Res 112: 295-302

Griffin AR, Burgess IP, Wolf L (1988) Patterns of natural and manipulated hybridisation in the genus Eucalyptus L'Hérit.—a review. Aust J Bot 36:41-66

Harbard JL, Griffin AR, Espejo J (1999) Mass controlled pollination of Eucalyptus globulus: a practical reality. Can J Forest Res 29:14571463

Horsley TN, Johnson SD (2007) Is Eucalyptus cryptically selfincompatible. Ann Bot-London 100:1373-1378

Horsley TN, Johnson SD, Stanger TK (2007) Optimum storage and in vitro germination of Eucalyptus pollen. Ann Bot 55:83-89

Horsley TN, Johnson SD, Myburg AA (2010) Comparison of different control-pollination techniques for small-flowered eucalypts. New For 39:75-88

Lee DJ, Huth JR, Osbourne DO, Hogg BW (2010) Selecting hardwood taxa for wood and fibre production in Queensland's subtropics. Aust Forest 73:106-114

Lord E (2000) Adhesion and cell movement during pollination: cherchez la femme. Trends Plant Sci 5:368-373

Martin F (1959) Staining and observing pollen tubes in the style by means of fluorescence. Stain Technol 34:125-128

Ngugi MR, Hunt MA, Doley D, Ryan P, Dart P (2004) Selection of species and provenances for low-rainfall areas: physiological responses of Eucalyptus argophloia to seasonal conditions in subtropical Queensland. Forest Ecol Manag 193:141-156

Nichols JD, Smith RG, Grant J, Glencross K (2010) Subtropical eucalypt plantations in eastern Australia. Aust Forest 73:53-62

Patterson B, Gore P, Potts BM, Vaillancourt RE (2004) Advances in pollination techniques for large-scale seed production in Eucalyptus globulus. Aust J Bot 52:781-788

Pound LM, Wallwork MAB, Potts BM, Sedgley M (2002a) Early ovule development following self- and cross-pollinations in Eucalyptus globulus Labill. ssp. globulus. Ann Bot 89:613-620
Pound LM, Wallwork MAB, Potts BM, Sedgley M (2002b) Selfincompatibility in Eucalyptus globulus ssp. globulus (Myrtaceae). Aust J Bot 50:365-372

Randall BW, Walton DA, Lee DJ, Wallace HM (2012) Fertilisation and pollen tube development in Eucalyptus argophloia. Silv Genet 61: $121-126$

Rockwood DL, Warrag EE, Javenshir K, Kratz K (1989) Genetic improvement for Eucalyptus grandis for Southern Florida. In: Proceedings of the 20th Southern Forest Tree Improvement Conference, Charleston, SC, pp 403-410

Sedgley M, Smith RM (1989) Pistil receptivity and pollen tube growth in relation to the breeding systems of Eucalyptus woodwardii Maiden (Symphyomyrtus). Ann Bot 64:21-31

Sedgley M, Hand FC, Smith RM, Griffin AR (1989) Pollen tube growth and early seed development in Eucalyptus regnans $\mathrm{F}$ Muell. (Myrtaceae) in relationship to ovule structure and preferential outcrossing. Aust J Bot 37:397-411

Sokal R, Rohlf F (1995) Biometry, 3rd edn. W. H. Freeman and Company, New York

Suitor S, Potts BM, Brown PH, Gracie AJ, Gore PL (2008) Postpollination capsule development in Eucalyptus globulus seed orchards. Aust J Bot 56:51-58

Tibbits WN (1989) Controlled pollination studies with shining Gum (Eucalyptus nitens (Deane \& Maiden) maiden). Forestry 62:111-126

Trindade H, Boavid LC, Borralho N, Feijo JA (2001) Successful fertilization and seed set from pollination on immature non-dehisced flowers of Eucalyptus globulus. Ann Bot 87:469-475

Turnbull JW (1999) Eucalypt plantations. New For 17:37-52

Van Wyk G (1977) Pollen handling, controlled pollination and grafting of Eucalyptus grandis. South African Forest J 101:47-53

Wallace HM, Vithanage V, Exley EM (1996) The effect of supplementary pollination on nut set of Macadamia (Proteaceae). Ann Bot 78:765773

White TL, Adams WT, Neale DB (2007) Forest genetics. CABI Publishing, Cambridge, MA

Williams DR, Potts BM, Black PG (1999) Testing single visit pollination procedures for Eucalyptus globulus and E. nitens. Aust Forest 62: 346-352 